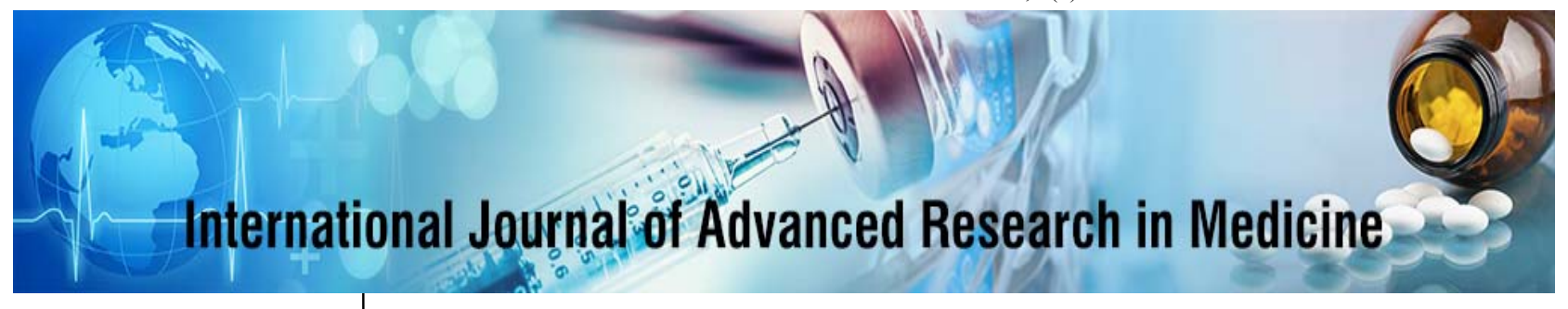

E-ISSN: 2706-9575 P-ISSN: 2706-9567 www.medicinepaper.net IJARM $2019 ; 1(1): 20-22$ Received: 01-12-2018 Accepted: 28-12-2018

Dr. Kaushal Kumar Sinha Fellow non-invasive Cardiology, GIPMER, Delhi, India

Dr. Nistha Kishore BSA Medical College, Delhi, India
Corresponding Author: Dr. Kaushal Kumar Sinha Fellow non-invasive Cardiology, GIPMER, Delhi, India

\section{To study the prevalence of nephropathy complication in newly diagnosed type 2 diabetes mellitus}

\author{
Dr. Kaushal Kumar Sinha and Dr. Nistha Kishore
}

DOI: https://doi.org/10.22271/27069567.2019.v1.i1a.27

\begin{abstract}
Background: Diabetes is one of the commonest chronic non communicable disease affecting the society at large both in developing and developed countries. Present study aimed to study Prevalence of nephropathy complication in newly diagnosed type 2 diabetes mellitus.

Subjects and Methods: In this study, 100 newly diagnosed cases of type 2 diabetes mellitus patients were evaluated. A cross section of both male and female diabetes patients diagnosed within the last 3 months (new onset) was taken into study. A detailed history, clinical examination and relevant investigations were performed. Collected data were analysed by using appropriate software.

Results: In our study $60 \%$ were male and $40 \%$ were female. Majority of cases were in the age group of 46-55 years, followed by in age group 56-65 years. Highest prevalence of nephropathy was seen in 5665 yrs age group. Nephropathy was present in $21.66 \%$ of male and $15 \%$ of female patients.

Conclusion: Endeavour should be made to control hyperglycemia tightly by appropriate therapeutic measures so that the occurrence and worsening of complications could be mitigated.
\end{abstract}

Keywords: nephropathy complication, type 2 diabetes mellitus

\section{Introduction}

Diabetes Mellitus (D.M.) refers to a group of common metabolic disorders that share the phenotype of hyperglycemia ${ }^{1}$. It results from a defect in insulin secretion and/or insulin action, which results in hyperglycaemia with disturbances of carbohydrate, fat and protein metabolism ${ }^{[2]}$.

Diabetes is one of the commonest chronic non communicable disease affecting the society at large both in developing and developed countries. It is generally classified as type 1, type 2 or other specific types ${ }^{[3]}$.

Type 1 diabetes is generally considered a $\mathrm{T}$ cell mediated autoimmune disease involving destruction of the insulin secreting $\beta$ cells in the pancreas, resulting in absolute insulin deficiency, whereas type 2 diabetes is characterised by resistance to the action of insulin and an inability to produce sufficient insulin to overcome this ' insulin resistance' ${ }^{[4]}$.

Globally, all types of diabetes are on the increase, type 2 diabetes in particular ${ }^{[5]}$. While diabetes has been known for many centuries, the prevalence has reached epidemic level proportion only recently ${ }^{[6]}$. The rise of prevalence has been more alarming in developing countries than in developed countries. There has also been a trend towards a shift in the mean age of onset of type 2 diabetes to a much younger age ${ }^{[7]}$.

As per the $9^{\text {th }}$ edition of International Diabetes Federation Atlas, 2019,. The global diabetes prevalence is estimated to be $9.3 \%$ (463 million people), rising to $10.2 \%$ (578 million) by 2030 and $10.9 \%$ (700 million) by 2045 . The major proportion of this increase will occur in developing countries of the world like India ${ }^{[8]}$. One in two $(50.1 \%)$ people living with diabetes do not know that they have diabetes.

India leads the world with largest number of diabetic subjects earning the dubious distinction of being termed the "Diabetes Capital of the World.

Type 2 diabetes is accompanied by a high prevalence of associated disorders like the various components of the metabolic syndrome like hypertension, dyslipidemia and obesity; micro vascular complications like retinopathy, nephropathy, neuropathy and macro vascular complications like coronary artery disease, peripheral vascular disease and cerebrovascular disease resulting in significantly high morbidity and mortality [9-14]. The chronic complications of diabetes mellitus translate into a significant economic burden on 
individuals and community at large ${ }^{[14]}$. Due to its asymptomatic course, type 2 diabetes evades diagnosis for many years. Harris et al. ${ }^{[15]}$ estimated a gap of 9 to 12 years between the onset of type 2 diabetes and its clinical diagnosis. Long standing diabetes mellitus is associated with an increased prevalence of microvascular and macrovascular complications. The first indication of the presence of type 2 diabetes mellitus may actually be detected at the time of diagnosis of a diabetic complication.

\section{Aims and Objectives}

To study the Prevalence of nephropathy complication in newly diagnosed type 2 diabetes mellitus.

\section{Materials and Methods}

In this study, 100 newly diagnosed cases of type 2 diabetes mellitus patients were evaluated. A cross section of both male and female diabetes patients diagnosed within the last 3 months (new onset) attending the general medicine indoor and outpatient department and other clinical departments of katihar medical college, katihar was taken into study.

A detailed history, clinical examination and relevant investigations were performed.

\section{History}

Age, sex and duration of diabetes were recorded. Family history of diabetes and personal medical history was enquired. History of symptoms suggestive of nephropathy complications like decreased urine output, body swelling were taken.

\section{Inclusion Criteria}

Patients with:

- Newly diagnosed case of type 2 diabetes mellitus

- Cases within 3 months of diagnosis

\section{Exclusion Criteria}

Patients with:

- Type 1 diabetes mellitus

- Diagnosed type 2 diabetes of more than 3 months duration

- Previous history of any vascular disease

- End stage renal disease

- Pre-existing neurological disease including stroke, dementia

- History of nephrotoxic, neurotoxic or oculotoxic drug use

\section{Biochemical Analysis}

Biochemical analysis of the following were done in the department of Biochemistry

Serum urea levels were determined spectrophotometrically using the product formed when urea reacted with diacetyl in the presence of a strong acid- method of Fearon. Normal value is $15-40 \mathrm{mg} / \mathrm{dl}$.

Serum creatinine estimation was done by the method of Brod and Sirota using Jaffe reaction. Normal value is up to $1.4 \mathrm{mg} / \mathrm{dl}$. Urinary albumin creatinine ratio (ACR) was done $<30 \mu \mathrm{g} / \mathrm{mg}$ was taken as normal, $30-300 \mu \mathrm{g} / \mathrm{mg}$ and $>300$ $\mu \mathrm{g} / \mathrm{mg}$ were considered to have microalbuminuria and macroalbuminuria respectively. Presence of microalbuminuria was taken as indicative for nephropathy when at least two out of three test was positive for microalbuminuria

\section{American Diabetes Association Guidelines 2019 (Ada 2019)}

- Fasting and/or 2 hr post 75 oral anhydrous glucose plasma glucose level was estimated by enzymatic glucose oxidation method. A basal $\mathrm{FPG}>126 \mathrm{mg} / \mathrm{dl}$, and a plasma glucose $>200 \mathrm{mg} / \mathrm{dl}$ at $2 \mathrm{hr}$ post 75 glucose confirmed on a second occasion was diagnostic of diabetes.

- Glycosylated haemoglobin (HbA1c) was estimated by ion exchange chromatography. In diabetes mellitus the value is $\geq 6.5$. It gives an idea of the plasma glucose control on the preceding 3 months.

\section{Result}

Table 1: Sex Wise Distribution of Population

\begin{tabular}{|c|c|c|}
\hline Sex & Number & \% Age \\
\hline Male & 60 & 60 \\
\hline Female & 40 & 40 \\
\hline
\end{tabular}

In our study $60 \%$ were male and $40 \%$ were female

Table 2: Distribution of Population in Different Age Group

\begin{tabular}{|c|c|c|}
\hline Age Groups (In Yrs) & Number & \% Age \\
\hline $36-45$ & 14 & 14 \\
\hline $46-55$ & 51 & 51 \\
\hline $56-65$ & 35 & 35 \\
\hline
\end{tabular}

Majority of cases were in the age group of 46-55 years, followed by in age group 56-65 years.

Table 3: Showing Prevalence of Nephropathy in Different Age Groups

\begin{tabular}{|c|c|c|c|}
\hline $\begin{array}{c}\text { Age } \\
\text { Group } \\
\text { (in yrs) }\end{array}$ & $\begin{array}{c}\text { Microalbuminuria } \\
\text { ACR 30-299MG/MG }\end{array}$ & $\begin{array}{c}\text { Macroalbu } \\
\text { minuria } \\
\text { ACR } \geq \\
\text { 300 } \boldsymbol{\mu G} / \mathbf{M G}\end{array}$ & Percentage \\
\hline $\begin{array}{c}36-45 \\
(\mathrm{~N}=14)\end{array}$ & 2 & 0 & 14.28 \\
\hline $\begin{array}{c}46-55 \\
(\mathrm{~N}=51)\end{array}$ & 4 & 1 & 9.80 \\
\hline $\begin{array}{c}56-65 \\
(\mathrm{~N}=35)\end{array}$ & 8 & 4 & 34.28 \\
\hline
\end{tabular}

Highest prevalence of nephropathy was seen in 56-65 yrs age group

Table 4: Showing Prevalence of Nephropathy in Male and Female

\begin{tabular}{|c|c|c|}
\hline Sex & No. of Patients & Percentage \\
\hline $\mathrm{M}(\mathrm{N}=60)$ & 13 & 21.66 \\
\hline $\mathrm{F}(\mathrm{N}=40)$ & 6 & 15 \\
\hline
\end{tabular}

Nephropathy was present in $21.66 \%$ of male and $15 \%$ of female patients.

\section{Discussion}

The present cross sectional study was carried out on 100 consecutive patients of type 2 diabetes who were diagnosed recently (duration less than 3 months). The mean age at diagnosis was found to be 53.7 years. This signifies that in 
our hospital, diabetic patients are presenting late. Among the newly diagnosed patients 60 were male and 40 patients were female.

Age wise analysis of the patients reveals that most of the patient were in age group 46-55 yrs $\mathrm{n}=51(51 \%)$, followed by in age group $56-65 n=35(35 \%)$ and least number in 35 $-45 n=14(14 \%)$. This corroborates with the work done by RAMACHANDRA et al. [16] which shows that in developing countries, the majority of diabetes patients are in the age range of 45-64 years whereas in the developed countries are aged $>65$ years. In our study $86 \%$ of population was in age group $46-65 \mathrm{yrs}$.

Nephropathy was seen $19(19 \%)$ of newly diagnosed diabetics. Study by AGRAWAL et al. ${ }^{[17]}$ from Jhansi had found the prevalence to be $17.34 \%$ which was quite similar to our study. WHO multicentric study ${ }^{[18]}$ of vascular disease in diabetes reported a wide variation in prevalence of nephropathy. It ranged from 2.4\% (Hong kong), 23\% (Delhi) to $37 \%$ (Oklahaoma, USA). Thus it can be concluded that prevalence of nephropathy varies considerably between different geographic regions. Multiple factors may be responsible for this like genetic predisposition, smoking pattern, coexisting hypertension or other socio economical and cultural/ environmental factors. Simultaneously quality and quantity of protein may also play an important role in evolution of diabetic nephropathy.

When assessing the prevalence of nephropathy using albuminuria, it is important to consider the prevalence of albuminuria in back ground population which may also contribute positively to the result. Nephropathy was seen in $13(21.66 \%)$ of male and $6(15 \%)$ of females. It was Statistically not significant $(P$ value $>0.05)$.

\section{Summary and Conclusion}

The study was carried out with the intent to assess the prevalence of nephropathy complication in the newly diagnosed type 2 diabetics.

Diabetic complications are fairly common in newly diagnosed type $2 \mathrm{DM}$ patients. The complications were more common in higher age group.

In summary, prevalence of complications is quite high even at the time of diagnosis of Type 2 diabetes. This is probably because of the insidious onset of diabetes and long duration of asymptomatic disease before symptoms develop. Hence screening tests for complications are strongly recommended at the time of diagnosis not only for early detection, but also to prevent the progression into end stage disease.

Endeavour should be made to control hyperglycemia and hypertension tightly by appropriate therapeutic measures so that the occurrence and worsening of complications could be mitigated.

There is an urgent need for concerted efforts by Government and Non-governmental sectors to implement national programmes aimed at prevention, management and surveillance of the disease.

\section{References}

1. Harrison's principles of Internal Medicine, $20^{\text {th }}$ edition 2018., P- 2850.

2. Hovens MMC, Van de loar FA et al. Acetylsalicyclic acid ( aspirin) for primary prevention of cardiovascular disease in type 2 diabetes (protocol) Cochrane database os systematic reviews 2005, issue 3. Art no. CD005446.
3. Mohan V, Pradeepa R, Anjana RM. Diabetes in IndiaAn Epidemiological review. Current Controversies and Consensus in Diabetes Management, $1^{\text {st }}$ edition 2015, P-1.

4. Davidson's principles \& practice of Medicine, $23^{\text {rd }}$ edition, 2018, P -728.

5. International Diabetes Federation - IDF Diabetes Atlas, $6^{\text {th }}$ edn. Brussels, Belgium: International Diabetes Federation, 2013.

6. Major RM. A history of medicine. Blackwell, oxford, 1954, P- 67.

7. Progress in Medicine. 2015; XXIX:164.

8. International Diabetes Federation. The Diabetes Atlas, $9^{\text {th }}$ ed. 2019.

9. Garcia MJ, McNamara PM, Gordon T, Kannel WB. Diabetes, 1974; 23:105-111.

10. Kannel WB, McGee DL. Circulation, 1979; 59:8-13.

11. Stamler J, Wentworth D, Neaton J, Schoenberger JA, Feigal D; for the MRFIT Research Group. Circulation, 1984; 70:11-161.

12. Haffner SM, Lehto S, Ronemaa T, Pyorala K, Laasko M. N Engl J Med,1998,339, 229-234.

13. Juutilainen A, Lehto $\mathrm{S}$, Ronnemaa $\mathrm{T}$, Pyorala $\mathrm{K}$, Laakso M. Diabetes Care, 2008; 31:714-719.

14. Wirta O, Pasternak A, Mustonen J, Laippala P, Lahde Y. Clin Nephrol, 1999; 51:329-334.

15. Harris MI, Klein R, Welborn TA, Knuiman MW. Onset of NIDDM ocurrs at least 4-7 $\mathrm{yr}$ before clinical diagnosis. Diabetes Care. 1992; 13:815-819.

16. Ramachandran A. Socioeconomic burden of diabetes in India.Suppl. JAPI, 2007; 55:9.

17. Agrawal RP, Ranka M, Beniwal R, Sharma S, Purohit VP, Kochar DK, et al. Prevalence of micro and macro vascular complications in type 2 diabetes and their risk factors int. j. diab. dev. Countries. 2004; 24:11.

18. Diabetes drafting group. Prevalence of small vessel and large vessel disease in diabetic patients from 14 centers. WHO multinational study of vascular disease in diabetics. Diabetologia, 1985; 28:615-40. 